Науковий вісник Дьвівського націонадьного університету ветеринарної медицини та біотехнодогій імені С.3. Гжицького

\author{
Scientific Messenger of Lviv National University \\ of Veterinary Medicine and Biotechnologies
}

\title{
Dynamics of morphological and biochemical indicators of blood of sucking piglets at different levels of iodine citrate in sows rations
}

\author{
R.V. Hunchak, H.M. Sedilo \\ Institute of Agriculture of Carpathian Region of Ukraine NAAS, Obroshino, Ukraine
}

Article info

Received 19.01.2018

Received in revised form 20.02.2018

Accepted 26.02.2018

Institute of Agriculture of Carpathian region of Ukraine, NAAS of Ukraine,

Grushevskogo Str., 5, Obroshino, 81115, Ukraine.

Tel.: +38-067-334-28-80 E-mail: roman.hunchak@gmail.com
Hunchak, R.V., \& Sedilo, H.M. (2018). Dynamics of morphological and biochemical indicators of blood of sucking piglets at different levels of iodine citrate in sows rations. Scientific Messenger of Lviv National University of Veterinary Medicine and Biotechnologies. 20(84), 27-32. doi: $10.15421 /$ nvlvet 8405

The article presents the results of experimental studies on the determination of the influence of iodine citrate on hematological and biochemical parameters of blood of sucking piglets. It was established that hemopoiesis and metabolic reactions in pigs depend on the level of Iodine in the sows, and in the later period (the 10th day) and from the receipt of the biometal as part of the prestarter. Iodine, in nanocitate form, at the expense of high bioavailability and chemical activity, provided the need for thyroid gland in it in much less quantities than the amounts recommended for pregnant and lactating sows in the form of potassium iodide. It has been established that at the admission to the body of a sow $0.095-0.19 \mathrm{mg} / \mathrm{kg}$ of feeding of iodine in a nanocyte form (1/4-1/2 of the recommended amount of iodine in the form of CI), its positive effect on hemopoiesis and metabolic processes in newborn piglets is peculiar (increased number of red blood cells, hemoglobin content, high percentage of lymphocytes, increases in the concentration of total protein and in particular albumin, against the backdrop of growth in blood plasma levels of CSF, the concentration of hormones $T_{3}$ and $T_{4}$ is quite stable. A higher dose in the premix of iodine citrate $(1: 1)$ is irrational and most likely undesirable, since against the background of inhibition of this group of erythropoiesis, eosinophilia and lymphopenia, the protein synthesis function decreases and the activity of AlAT, AsAT increases. Hematological and biochemical parameters of blood of piglets obtained from sows, which received a minimum amount of iodine in the form of citrate $(0.1: 1)$ with premix, did not undergo significant changes, were within the limits of physiological values, although in comparison with the animals of the control group, and particularly, the piglets of the group D2 and D3 tended to decrease (growth). Consequently, iodine citrate as a source of iodine for pregnant and subsistence sows can be recommended in the amounts: $0.095-0.19 \mathrm{mg} / \mathrm{kg}$ and $0.125-0.25 \mathrm{mg} / \mathrm{kg}$ feed.

Key words: iodine citrate, premix, sows, piglets, hemopoiesis.

\section{Динаміка морфологічних та біохімічних показників крові підсисних поросят за різного рівня аквацитрату йоду в раціонах свиноматок}

\author{
Р.В. Гунчак, Г.М. Седіло
}

Інститут сільського господарства Карпатського регіону України НААН, с. Оброшино, Україна

У статті подано результати експериментальних досліджень щзодо з'ясування впливу цитрату йоду на гематологічні і біохімічні показники крові підсисних поросят. Встановлено, шуо гемопоез та обмінні реакції у поросят залежали від рівня Йоду в організмі свиноматок, а у більш пізній період (10-а доба) - i від надходження біоелементу у складі престартера. Йод, у наноцитратній формі, за рахунок високої біодоступності та хімічної активності забезпечував потребу щзитоподібної залози в ньому в значно менших кількостях, ніж кількості, рекомендовані для супоросних і лактуючих свиноматок у формі калію йодиду. Встановлено, щчо за поступлення в організм свиноматок 0,095-0,19 мг/кг корму Йоду у наноцитратній формі (1/4-1/2 від рекомендованої кількості Йоду у формі КІ) характерним є позитивний його вплив на гемопоез і метаболічні процеси у новонароджених поросят (зростає кількість еритроцитів, вміст гемоглобіну; високий відсоток лімфоцитів, підвишується концентрація загального протеїну $і$ зокрема альбумінів, на тлі зростання у плазмі крові рівня ЙЗБ концентраџія гормонів $T_{3} i T_{4} \epsilon$ доволі стабільною. Більи висока доза в складі преміксу изитрату йоду (1:1) є нераціональною і найімовірніме, небажаною, оскільки на тлі пригнічення у поросят изієі групи еритропоезу, еозинофілї $і$ лімфопенії знижується білоксинтезувальна функція та зростає активність АлАТ і АсАТ. Гема- 
тологічні та біохімічні показники крові поросят, отриманих від свиноматок, які з преміксом отримували мінімальну досліджувану кількість Йоду у формі аквацитрату (0,1 : 1), суттєвих змін не зазнавали, перебували у межах фізіологічних величин, хоч порівняно з тваринами контрольної групи, особливо поросятами групи Д $і$ і Дз мали тендениію до зниження (зростання). Отже, иитрат йоду як джерело Йоду для супоросних і підсисних свиноматок може бути рекомендований у кількостях: 0,095-0,19 мг/кг і 0,1250,25 мг/кг корму.

Ключові слова: аквацитрат йоду, свиноматки, підсисні поросята, гематологічні та біохімічні показники крові.

\section{Вступ}

Нарощування виробництва продукції свинарства вимагає, насамперед, забезпечення свиней повноцінною годівлею, в тому числі з використанням біологічно активних добавок, серед яких макро- і мікроелементам належить провідна роль (Klitsenko et al., 2001; Kokorev et al., 2005; Medvid et al., 2017; Rud, 2017; Zhukova et al., 2017). Вони забезпечують перебіг найважливіших біохімічних реакцій, в результаті яких виділяється енергія для підтримання життєдіяльності тварин, відбувається поділ і ріст клітин, здійснюється імунний захист, забезпечується баланс внутрішнього середовища організму. До числа лімітуючих мікроелементів відноситься Йод, оскільки за його дефіциту, як і за надлишку, в організмі тварин порушується обмін речовин, знижується продуктивність, виникають захворювання, які можуть призвести до летальних наслідків (Vorob'ev, 2011; Hunchak et al., 2016; Gutyj et al., 2017).

Потреба свиней у Йоді не є постійною і незмінною константою. На неї впливають генетичні, фізіологічні, екологічні й аліментарні чинники (Antonjak, 1999; Antoniak, 2002; Lugovoy et al., 2017). У тварин різних порід, віку, фізіологічного стану (період росту, розмноження, лактація) забезпечення Йодом різниться i визначається зростанням чутливості тварин до його дефіциту. Відповідний рівень надходження Йоду в організм вагітних тварин, зокрема супоросних свиноматок, необхідний для росту і розвитку плодів, становлення функцій їх нервової системи. Водночас нестача Йоду у них підвищує небезпеку перед- і післяродових ускладнень у репродуктивній системі матері. За інтенсивного росту свиней Йод, через систему гормонів щитоподібної залози, забезпечує основний метаболізм в організмі тварин та функціонування органів і тканин (Preedy et al., 2009; Suttle, 2010).

При нестачі Йоду у раціонах супоросних свиноматок характерним є порушення нормальної відтворювальної здатності, народжуються недорозвинуті поросята з ознаками вираженого зобу, рідким волосяним покривом. Як правило, такі поросята нежиттєздатні, швидше гинуть (Hryshko et al., 2008; Hunchak and Sedilo, 2017). Джерелом поступлення Йоду в організм підсисних поросят, особливо в перші 10 днів постнатального періоду, є виключно молозиво і молоко свиноматок. У молозиві вміст Йоду в кілька разів може бути більшим, ніж у молоці. Причому, на думку окремих авторів наукових повідомлень, із зростанням періоду лактації концентрація Йоду в молоці поступово зменшується. Це може сприяти зниженню в організмі підсисного молодняку рівня Йоду, що в кінцевому підсумку сприятиме пригніченню метаболічних процесів (Hryshko et al., 2008; Suttle, 2010). Йодозалежні гормони щитоподібної залози є потуж- ними біорегуляторами, які, діючи на численні ланки внутрішньоклітинного метаболізму, визначають інтенсивність процесів росту і диференціації клітин під час пре- і неонатального періодів розвитку та функціональну активність клітин у дорослому організмі. Багатогранний вплив йодотиронінів на фізіологічні та метаболічні функції клітин здійснюється шляхом регуляції функціонування транспортних систем мембран, інтенсивності надходження до клітин Оксигену, активності внутрішньоклітинних окисно-відновних реакцій, процесів термогенезу, обміну білків, нуклеїнових кислот, вуглеводів, ліпідів. Як відомо, розлади функціональної активності щитоподібної залози призводять до порушення діяльності ряду систем, зокрема імунної і кровотворної (Svarchevska et al., 2014; Hunchak et al., 2018).

Метою досліджень було вивчення морфологічних i біохімічних показників крові у підсисних поросят, народжених від свиноматок, що в період супоросності отримували з раціоном аквацитрат йоду в різних кількостях.

\section{Матеріал і методи досліджень}

Дослідження проведено в умовах ФГ «Аміла» Турійського району Волинської області на ремонтних свинках $\mathrm{F}_{1}$ від чистих материнських ліній породи Ландрас $\times$ Велика біла, віком 170-180 днів, що досягали маси 115-120 кг. Годівля піддослідних тварин проводилась дворазово, відповідно до існуючих норм 3 вільним доступом до води. При цьому використовували повнораціонні комбікорми 3 включенням до їхнього складу злакової групи концентрованих кормів власного виробництва. Для збалансування раціонів за макро- мікро-вітамінним складом у всі періоди досліду (свиноматки супоросні і підсисні) тваринам задавали премікси, виготовлені за відповідною рецептурою у ТОВ «АБМ-ТРЕЙД». Вміст Йоду у таких преміксах для супоросних свиноматок становив 0,38, а для підсисних - 0,50 мг/кг корму.

3 метою вивчення дії наноорганічної форми Йоду і можливого введення ii до складу преміксу, нами використано аквацитрат йоду, вироблений на основі нанотехнологій ТОВ «НВК Аватар» (активність 1 г на 1 л розчину). Відповідно до схеми досліду було сформовано 5 груп тварин: контрольна (К) і 4-и дослідних ( Д $\left._{1}, Д_{2}, Д_{3}, Д_{4}\right)$. Тварини контрольної групи (супоросні та підсисні свиноматки) отримували стандартний премікс, до складу якого входив калію йодид у рекомендованій дозі. Дослідним групам тварин згодовували премікси, позбавлені Йоду. Проте, їм до раціону, шляхом зволоження сухого корму, вводили водний розчин цитрату йоду в кількостях, що були еквівалентні дозі Йоду у формі калію йодиду в співвідношеннях: Д $-1: 1$ (0,38 і 0,5 мг/кг); Д $2-0,5: 1(0,19$ i 
$0,25 \mathrm{мг} / \kappa г) ; Д_{3}-0,25: 1$ (0,095 і 0,125 мг/кг); Д 4 $0,1: 1(0,038$ і 0,05 мг/кг).

У новонароджених поросят, що отримані від свиноматок контрольної і дослідних груп, відбирали кров на 9, 18 і 27-у доби досліджень та визначали в ній: кількість еритроцитів - фотонефелометрично, за методикою Є.С. Гаврилець і співавт. (1966); число лейкоцитів - за допомогою сітки Горяєва у лічильній камері (В.Е. Чумаченко, 1991). Лейкограму (відсоток різних форм лейкоцитів) встановлювали шляхом дослідження мазків крові, пофарбованих за методом Романовського-Гімзи, концентрацію гемоглобіну гемоглобінціанідним методом за Г.В. Дервіз і А.Г. Воробйовим (1959). У сироватці крові визначали рівень загального протеїну біуретовою пробою, а вміст окремих його фракцій - турбідиметричним методом; активність амінотрансфераз (АлАТ і АсАТ) за методом Райтмана-Френкеля; лужної фосфатази за реакцією з динатрійфенілфосфатом, концентрацію трийодтироніну $\left(\mathrm{T}_{3}\right)$, тироксину $\left(\mathrm{T}_{4}\right)$ i рівень Йоду, зв'язаного з білком - за методами, описаними у довіднику «Лабораторні методи досліджень у біології, тваринництві та ветеринарній медицині» (Vlizlo, 2012).

\section{Результати та їх обговорення}

За аналізом отриманих в експерименті результатів 3'ясовано, що гематологічні та досліджувані біохімічні показники крові поросят змінювалися із віком та залежали від поступлення в організм матері, а 3 10добового віку разом із престартером Йоду. Нами встановлено, що на 9-у добу досліджень, тобто в період, коли єдиним джерелом забезпечення організму поросят есенціальними мікроелементами є молозиво і молоко свиноматок, гематологічні показники були дозозалежними від поступлення в організм матері Йоду в формі аквацитрату (табл. 1).

\section{Таблиця 1}

Морфологічні показники крові підсисних поросят за різного рівня аквацитрату йоду в преміксах для свиноматок (9-а доба) $(\mathrm{M} \pm \mathrm{m}, \mathrm{n}=10)$

\begin{tabular}{lccccc}
\hline \multirow{2}{*}{ Показники } & \multicolumn{5}{c}{ Групи тварин } \\
\cline { 2 - 6 } & \multicolumn{2}{c}{ Контроль } & \multicolumn{4}{c}{ Дослід } \\
\cline { 2 - 6 } & К & 1 & 2 & 3 & 4 \\
\hline Еритроцити, Т/л & $5,22 \pm 0,62$ & $5,04 \pm 0,42$ & $5,30 \pm 0,88$ & $5,48 \pm 0,52$ & $5,30 \pm 0,45$ \\
Гемоглобін, Г/л & $108,4 \pm 2,6$ & $112,8 \pm 3,9$ & $122,6 \pm 4,2^{* * *}$ & $120,4 \pm 4,4^{*}$ & $112,2 \pm 5,3$ \\
Лейкоцити, Г/л & $9,86 \pm 0,82$ & $10,64 \pm 1,20$ & $9,98 \pm 0,82$ & $10,12 \pm 1,41$ & $10,24 \pm 1,0$ \\
Лейкограма, \% & & & & 0 & 0 \\
Базофіли & 0 & 0 & 0 & $1,8 \pm 0,1$ & $1,6 \pm 0,3$ \\
Еозинофіли & $1,6 \pm 0,2$ & $1,8 \pm 0,4$ & $1,8 \pm 0,1$ & $1,6 \pm 0,5$ & $1,4 \pm 0,1$ \\
Нейтрофіли (П) & $1,8 \pm 0,3$ & $1,8 \pm 0,3$ & $1,8 \pm 0,2$ & $18,6 \pm 3,2$ & $18,2 \pm 1,8$ \\
Нейтрофіли (С) & $19,8 \pm 2,1$ & $30,0 \pm 1,9$ & $26,2 \pm 2,7$ & $78,0 \pm 5,2$ & $70,8 \pm 6,4$ \\
Лімфоцити & $76,8 \pm 3,7$ & $66,4 \pm 2,8$ & $78,2 \pm 4,4$ & 0 & 0 \\
Моноцити & 0 & 0 & 0 & 0 & 0 \\
\hline
\end{tabular}

Так, вміст еритроцитів у крові поросят, народжених від свиноматок другої і третьої дослідних груп був вищим за аналогічний показник поросят контрольної групи на 3,1 і 5,0\%. При цьому в крові поросят також вищим був і рівень гемоглобіну (на 13,1 i $11,1 \%$ ). На тлі незначного зростання кількості лейкоцитів особливих відхилень у структурі окремих клітин білої крові не відзначено. Гематологічні показники поросят, народжених від свиноматок, що отримували 3 кормом Йод у формі цитрату в кількостях, що еквівалентні рівню біоелементу в неорганічній формі (група Д 1 ) та меншій за неї в 10 разів (група Д 4 ) були в цей період близькими до аналогічних у контрольній групі поросят i не виходили за межі фізіологічних величин.

Більш характерними в цей період неонатального розвитку були зміни в біохімічних показниках крові поросят (табл. 2). Нами відзначено, що за рівнем загального протеїну у сироватці крові та його альбумінової фракції кращий результат отримано в поросят другої та третьої дослідних груп. Отримані показники, порівняно з тваринами контрольної групи мали виражену тенденцію до зростання. I навпаки, за збільшення кількості Йоду у формі аквацитрату в раціонах свиноматок (група Д 1 ) концентрація загального протеїну знижувалась на 10,8\%, причому відсоток альбумінів був вірогідно нижчим на 20,5\% (P < 0,01). Динаміка зміни активності амінотрансфераз (АлАТ, АсАТ) та лужної фосфатази (ЛФ) не мала характерної закономірності в жодній із дослідних груп свиней, хоч у поросят четвертої групи спостерігалась тенденція до підвищення активності ензимів. Цікавими, на нашу думку, є отримані результати щодо концентрації Йоду, зв'язаного з білком (ЙЗБ) та тиреотонінів в плазмі крові поросят. Вміст ЙЗБ і гормонів $\mathrm{T}_{3} \mathrm{i}_{4}$ був відносно стабільним у крові поросят контрольної і дослідних груп поросят і мало залежав від надходження Йоду в організм свиноматок.

Концентрація ЙЗБ в крові поросят групи Д 4 була нижчою за показник контролю на 9,1\%, хоча свиноматки цієї групи отримували лише 1/10 кількості Йоду в наноцитратній формі. 
Таблиця 2

Вплив аквацитрату йоду в преміксах для свиноматок на окремі біохімічні показники крові підсисних поросят (9-а доба) $(\mathrm{M} \pm \mathrm{m}, \mathrm{n}=10)$

\begin{tabular}{|c|c|c|c|c|c|}
\hline \multirow{3}{*}{ Показники } & \multicolumn{5}{|c|}{ Групи тварин } \\
\hline & \multirow[t]{2}{*}{ Контроль } & \multicolumn{4}{|c|}{ Дослід } \\
\hline & & 1 & 2 & 3 & 4 \\
\hline Протеїн, загальний, г/л & $65,8 \pm 2,4$ & $58,7 \pm 3,6$ & $68,1 \pm 2,8$ & $67,4 \pm 3,6$ & $62,9 \pm 4,8$ \\
\hline Альбуміни, \% & $36,6 \pm 1,7$ & $29,1 \pm 2,0^{* *}$ & $37,9 \pm 1,1$ & $38,8 \pm 2,4$ & $34,9 \pm 3,4$ \\
\hline Глобуліни, \% & $63,4 \pm 1,8$ & $70,9 \pm 1,4$ & $62,1 \pm 2,8$ & $61,2 \pm 3,4$ & $65,1 \pm 2,2$ \\
\hline АлАТ, од./л & $34,6 \pm 2,2$ & $44,0 \pm 3,4$ & $35,1 \pm 3,3$ & $37,0 \pm 1,8$ & $40,2 \pm 1,8$ \\
\hline АсАТ, од./л & $42,8 \pm 3,5$ & $48,8 \pm 2,2$ & $40,8 \pm 3,7$ & $43,4 \pm 4,1$ & $45,4 \pm 4,0$ \\
\hline ЛФ, од/л & $1884,3 \pm 22,6$ & $1812,6 \pm 33,4$ & $1880,6 \pm 20,9$ & $1916,1 \pm 28,7$ & $1998,4 \pm 26,5$ \\
\hline ЙЗБ, мкг\% & $2,09 \pm 0,18$ & $2,28 \pm 0,15$ & $2,20 \pm 0,28$ & $1,94 \pm 0,05$ & $1,90 \pm 0,27$ \\
\hline $\begin{array}{l}\text { Трийодтиронін }\left(\mathrm{T}_{3}\right) \\
\text { нмоль/л }\end{array}$ & $1,44 \pm 0,12$ & $1,56 \pm 0,24$ & $1,50 \pm 0,30$ & $1,48 \pm 0,14$ & $1,32 \pm 0,34$ \\
\hline Тироксин $\left(\mathrm{T}_{4}\right)$ нмоль/л & $38,80 \pm 3,12$ & $45,26 \pm 4,88$ & $44,14 \pm 5,16$ & $39,02 \pm 6,02$ & $37,08 \pm 3,88$ \\
\hline
\end{tabular}

Подібною, за ймовірно достатньої кількості Йоду для функціонування щитоподібної залози, була ситуація із рівнем трийодтироніну і тироксину в їхній крові. Збільшення кількості Йоду, що поступав свиноматкам у формі цитрату $(1: 1)$ чи його зменшення в раціонах до мінімально досліджуваної кількості $(0,1: 1)$, порівняно 3 контролем, не сприяло вірогідним змінам показників, які характеризують гормоносинтезувальну функцію щитоподібної залози.
Очевидно, що за зниження чи збільшення поступлення Йоду в організм його надходження до щитоподібної залози залежить від біодоступності регулюється тиреотропним гормоном і зберігається на рівні, здатному забезпечити відповідний гормоногенез за рахунок зниження або зростання концентрації Йоду в плазмі та сечі.

Подібна залежність відзначена нами і в наступні періоди досліду 18 і 27 -а доба (табл. 3).

Таблиця 3

Динаміка гематологічних показників у підсисних поросят за різного рівня Йоду в організмі ( $\mathrm{M} \pm \mathrm{m}, \mathrm{n}=10)$

\begin{tabular}{|c|c|c|c|c|c|}
\hline \multirow{3}{*}{ Показники } & \multicolumn{5}{|c|}{ Групи тварин } \\
\hline & \multirow{2}{*}{$\begin{array}{c}\text { Контроль } \\
\text { (К) }\end{array}$} & \multicolumn{4}{|c|}{ Дослід } \\
\hline & & 1 & 2 & 3 & 4 \\
\hline \multicolumn{6}{|c|}{ 18-а доба } \\
\hline Еритроцити, Т/л & $5,60 \pm 0,34$ & $5,17 \pm 0,58$ & $5,80 \pm 0,33$ & $5,72 \pm 0,37$ & $5,46 \pm 0,60$ \\
\hline Гемоглобін, г/л & $112,6 \pm 4,4$ & $112,4 \pm 3,8$ & $115,0 \pm 5,6$ & $116,2 \pm 6,2$ & $112,4 \pm 4,5$ \\
\hline Лейкоцити, Г/л & $10,84 \pm 0,90$ & $11,88 \pm 1,12$ & $10,92 \pm 0,98$ & $10,58 \pm 1,0$ & $11,16 \pm 0,10$ \\
\hline \multicolumn{6}{|l|}{ Лейкограма, \% } \\
\hline Базофіли & 0 & 0 & 0 & 0 & 0 \\
\hline Еозинофіли & $1,9 \pm 0,2$ & $2,6 \pm 0,4$ & $2,0 \pm 0,3$ & $1,9 \pm 0,2$ & $2,0 \pm 0,4$ \\
\hline Нейтрофіли (П) & $2,9 \pm 0,4$ & $3,4 \pm 0,1$ & $3,1 \pm 0,4$ & $3,0 \pm 0,3$ & $3,1 \pm 0,2$ \\
\hline Нейтрофіли (С) & $25,0 \pm 3,7$ & $39,4 \pm 4,4$ & $26,2 \pm 2,8$ & $26,2 \pm 3,1$ & $29,3 \pm 3,2$ \\
\hline Лімфоцити & $70,2 \pm 4,9$ & $54,6 \pm 5,5$ & $68,7 \pm 5,0$ & $68,9 \pm 3,7$ & $63,7 \pm 6,4$ \\
\hline Моноцити & 0 & 0 & 0 & 0 & 0 \\
\hline \multicolumn{6}{|c|}{ 27-а доба } \\
\hline Еритроцити, Т/л & $5,66 \pm 0,45$ & $5,20 \pm 0,33$ & $5,42 \pm 0,45$ & $5,58 \pm 0,25$ & $5,52 \pm 0,33$ \\
\hline Гемоглобін, г/л & $112,2 \pm 5,6$ & $106,4 \pm 4,8$ & $116,9 \pm 6,1$ & $114,5 \pm 5,7$ & $111,8 \pm 4,9$ \\
\hline Лейкоцити, Г/л & $12,60 \pm 0,44$ & $13,11 \pm 0,67$ & $12,04 \pm 0,80$ & $12,40 \pm 0,55$ & $12,72 \pm 0,84$ \\
\hline Лейкограма, \% & & & & & \\
\hline Базофіли & $1,0 \pm 0,08$ & $2,0 \pm 0,07$ & $2,0 \pm 0,05$ & $2,0 \pm 0,05$ & $1,0 \pm 0,08$ \\
\hline Еозинофіли & $2,6 \pm 0,3$ & $3,3 \pm 0,2$ & $2,4 \pm 0,2$ & $2,2 \pm 0,3$ & $2,8 \pm 0,3$ \\
\hline Нейтрофіли (П) & $3,4 \pm 0,4$ & $3,4 \pm 0,5$ & $3,4 \pm 0,4$ & $3,0 \pm 0,6$ & $3,0 \pm 0,1$ \\
\hline Нейтрофіли (С) & $33,5 \pm 4,7$ & $43,9 \pm 3,5$ & $1,4 \pm 5,5$ & $30,2 \pm 6,7$ & $36,0 \pm 3,9$ \\
\hline Лімфоцити & $58,1 \pm 5,9$ & $46,0 \pm 6,7$ & $60,8 \pm 5,5$ & $62,6 \pm 7,4$ & $56,2 \pm 5,9$ \\
\hline Моноцити & $1,4 \pm 0,09$ & $1,4 \pm 0,1$ & $1,5 \pm 0,1$ & $1,4 \pm 0,08$ & $1,4 \pm 0,09$ \\
\hline
\end{tabular}

Кількість еритроцитів та вміст гемоглобіну в крові поросят дослідних другої і третьої груп були близькими до показників поросят контрольної групи. За надходження в їх організм з молоком і престартером Йоду в більшій кількості (група Д 1 ) у крові на 18 і 27 у доби життя знижується кількість еритроцитів на відповідно 7,7 і 8,1\%. На тлі незначного зростання в крові числа лейкоцитів характерною була еозинофілія і лімфоцитопенія. Відсоток лімфоцитів на 18-у добу життя поросят знижувався на $22,2 \%$, а на $27-y-$ на $20,8 \%(\mathrm{P}<0,01)$.

Гематологічні показники в поросят четвертої групи, що отримували мінімальну досліджувану кількість Йоду у формі цитрату, суттєвих змін не зазнавали, перебували у межах фізіологічних величин, хоч порівняно $з$ тваринами контрольної групи, особливо 
поросятами групи Д 2 і Д3, мали тенденцію до зниження.

За оцінкою білоксинтезувальної функції (табл. 4) кращий результат на 18 і 27-у доби досліду відзначено у поросят другої і третьої груп. Очевидно, що половинна і навіть четвертинна частка Йоду у формі цитрату $\epsilon$ достатньою для забезпечення метаболічних процесів в організмі тварин, оскільки рівень загального протеїну у сироватці крові поросят цих груп був на рівні аналогічного показника поросят контрольної групи, а за відсотком альбумінів на 27-у добу пере- вищував його на 14,1\%. Нами підтверджено, що Йод у формі цитрату має кращу біодоступність. Концентрація ЙЗБ у плазмі крові поросят, особливо у перші дні після включення його до складу престартера, була на $13,4 \%$ вищою, ніж у поросят, що отримували 3 преміксом обгрунтовану кількість Йоду в неорганічній формі. В подальшому, очевидно через зростання потреби в біометалі для гормоносинтезувальної функції, а можливо, і через посилене виділення Йоду з сечею рівень ЙЗБ в крові поросят дещо знижувався.

Таблиця 4

Вплив різної концентрації Йоду в організмі поросят на біохімічний профіль їх крові, $(\mathrm{M} \pm \mathrm{m}, \mathrm{n}=10)$

\begin{tabular}{|c|c|c|c|c|c|}
\hline \multirow{3}{*}{ Показники } & \multicolumn{5}{|c|}{ Групи тварин } \\
\hline & \multirow{2}{*}{$\begin{array}{l}\text { Контроль } \\
\text { (К) }\end{array}$} & \multicolumn{4}{|c|}{ Дослід } \\
\hline & & 1 & 2 & 3 & 4 \\
\hline \multicolumn{6}{|c|}{ 18-а доба } \\
\hline Протеїн, загальний, г/л & $68,9 \pm 3,0$ & $60,0 \pm 2,2$ & $69,4 \pm 4,4$ & $70,7 \pm 3,5$ & $64,7 \pm 3,3$ \\
\hline Альбуміни, \% & $42,3 \pm 1,9$ & $40,6 \pm 2.9$ & $45,8 \pm 1,8$ & $44,1 \pm 3,7$ & $40,3 \pm 3,0$ \\
\hline Глобуліни, \% & $57,7 \pm 3,8$ & $59,4 \pm 5,4$ & $44,2 \pm 4,7$ & $55,9 \pm 6,0$ & $59,7 \pm 3,7$ \\
\hline АлАТ, од./л & $44,7 \pm 4,4$ & $50,7 \pm 4,0$ & $45,4 \pm 3,7$ & $42,8 \pm 3,7$ & $46,4 \pm 4,3$ \\
\hline АсАТ, од./л & $40,1 \pm 3,7$ & $43,7 \pm 3,6$ & $40,9 \pm 4,0$ & $39,7 \pm 3,0$ & $40,9 \pm 2,9$ \\
\hline ЛФ, од/л & $1566,7 \pm 34,3$ & $1690,9 \pm 30,2$ & $1616,4 \pm 45,5$ & $1600,8 \pm 58,7$ & $1660,6 \pm 40,8$ \\
\hline ЙЗБ, мкг\% & $2,68 \pm 0,36$ & $3,32 \pm 0,56$ & $3,04 \pm 0,45$ & $2,82 \pm 0,82$ & $2,50 \pm 0,32$ \\
\hline Трийодтиронін $\left(\mathrm{T}_{3}\right)$ нмоль/л & $2,12 \pm 0,24$ & $2,34 \pm 0,18$ & $2,20 \pm 0,32$ & $2,28 \pm 0,34$ & $2,00 \pm 0,27$ \\
\hline Тироксин $\left(\mathrm{T}_{4}\right)$ нмоль/л & $46,80 \pm 4,62$ & $50,16 \pm 5,27$ & $48,20 \pm 5,98$ & $48,12 \pm 4,66$ & $45,82 \pm 3,90$ \\
\hline \multicolumn{6}{|c|}{ 27-а доба } \\
\hline Протеїн, загальний, г/л & $57,7 \pm 4,2$ & $52,2 \pm 6,0$ & $63,7 \pm 3,7$ & $60,7 \pm 4,9$ & $62,5 \pm 5,8$ \\
\hline Альбуміни, \% & $41,7 \pm 5,0$ & $36,2 \pm 3,1$ & $47,6 \pm 3,5$ & $43,6 \pm 2,9$ & $42,5 \pm 3,8$ \\
\hline Глобуліни, \% & $58,3 \pm 3,7$ & $63,8 \pm 5,7$ & $52,4 \pm 5,1$ & $66,4 \pm 5,5$ & $57,5 \pm 4,7$ \\
\hline АлАТ, од./л & $53,7 \pm 5,6$ & $54,9 \pm 3,2$ & $53,7 \pm 3,3$ & $52,6 \pm 2,9$ & $54,9 \pm 4,0$ \\
\hline АсАТ, од./л & $32,3 \pm 2,7$ & $36,7 \pm 3,7$ & $33,9 \pm 2,3$ & $33,7 \pm 3,5$ & $34,7 \pm 2,9$ \\
\hline ЛФ, од/л & $488,6 \pm 11,2$ & $812,8 \pm 9,6$ & $496,6 \pm 10,0$ & $462,4 \pm 7,7$ & $580,8 \pm 9,4$ \\
\hline ЙЗБ, мкг\% & $2,96 \pm 0,23$ & $3,86 \pm 0,20$ & $3,02 \pm 0,25$ & $3,12 \pm 0,35$ & $2,88 \pm 0,20$ \\
\hline Трийодтиронін (Т3) нмоль/л & $2,62 \pm 0,36$ & $2,89 \pm 0,18$ & $2,72 \pm 0,25$ & $2,59 \pm 0,29$ & $2,48 \pm 0,38$ \\
\hline Тироксин (Т4) нмоль/л & $44,52 \pm 4,12$ & $49,66 \pm 6,14$ & $46,14 \pm 5,02$ & $46,48 \pm 6,18$ & $42,16 \pm 3,52$ \\
\hline
\end{tabular}

Зростання на 18 і 28-у доби досліду в плазмі крові поросят першої групи (Д $)$ рівня ЙЗБ на 23,9 і 30,4\% характеризувалося відносно незначним посиленням синтезу тиреотонінів. Концентрація гормонів $\mathrm{T}_{3} \mathrm{i}_{4}$, за цих умов була вищою за показник контролю лише на 10,3 і 11,5\%, відповідно.

Таким чином, підсумовуючи наведене вище, можна висловити припущення, що аквацитрат йоду може бути джерелом Йоду для свиней у значно менших дозах, ніж його аналог - калію йодид, що $є$ неорганічною формою. Навіть 1/10 кількості Йоду, що задається в наноцитратній формі, здатна забезпечити відповідний рівень в крові ЙЗБ та тиреотропних гормонів $\mathrm{T}_{3} \mathrm{i}_{4}$, а наявний позитивний вплив аквацитрату йоду на гемопоез та метаболічні процеси за введення його в 1/2-1/4 дози калію йодиду є предметом дискусії щодо обгрунтованості рекомендованої дози Йоду в складі преміксів.

\section{Висновки}

Акваитрат йоду, будучи високоактивною і біодоступною сполукою забезпечує відповідні стандарти породи та продуктивні якості свиноматок за умови введення до їх раціонів Йоду у формі аквацитрату в кількостях: для супоросних свиноматок - 0,1950,19 мг/кг; для підсисних - 0,125-0,25 мг/кг корму. До складу престартеру для підсисних поросят рекомендуємо вводити цитрат йоду зі вмістом Йоду 0,25 мг/кг корму.

Перспектива наукових досліджень. Подальші дослідження будуть спрямовані на вивчення впливу Йоду у формі цитрату на відгодівельні якості свиней та хімічний склад м'яса.

\section{References}

Antoniak, H.L. (2002). Osoblyvosti hemopoezu u tvaryn na rannikh stadiiakh postnatalnoho rozvytku: Avtoref. dys. dok. biol. nauk: 03.00.04. Lviv, 29 (in Ukrainian).

Antonjak, G.L. (1999). Vlijanie tiroksina i insulina na process krovetvorenija $\mathrm{u}$ zhivotnyh $\mathrm{v}$ neonatal'nom periode razvitija. 41(6), 512-516 (in Russian).

Gutyj, B., Leskiv, K., Shcherbatyy, A., Pritsak, V., Fedorovych, V., Fedorovych, O., Rusyn, V., \& Kolomiiets, I. (2017). The influence of Metisevit on biochemical and morphological indicators of blood of piglets under 
nitrate loading. Regulatory Mechanisms in Biosystems. 8(3), 427-432. doi: 10.15421/021766

Hryshko, V., Nikitenko, A., \& Malyna, V. (2008). Polipshennia hematolohichnykh pokaznykiv $\mathrm{u}$ porosiat-sysuniv. Tvarynnytstvo Ukrainy. 10, 22-25 (in Ukrainian).

Hunchak, A.V., Ratych, I.B., Gutyj, B.V., \& Paskevych, H.A. (2016). Metabolic effects of iodine in poultry for its deficiency or excess in the diet. Scientific Messenger LNUVMBT named after S.Z. Gzhytskyj. 18, 2(67), 70-76. doi:10.15421/nvlvet6716

Hunchak, R.V., \& Sedilo, H.M. (2017). Iodine deficiency in pigs and the solutions to the problem. Scientific Messenger of Lviv National University of Veterinary Medicine and Biotechnologies. 19(74), 208-214. doi:10.15421/nvlvet7445

Hunchak, R.V., Sedilo, H.M., Kystsiv, V.O., Gutyj, B.V., \& Hunchak, V.M.(2018). Total liquid maintenance and correlation of their classes in the sow's colostrum and milk at different levels of aquacart of Iodine in their rations. Ukrainian Journal of Ecology, 8(1), 644648. doi: 10.15421/2017 261

Klitsenko, H.T., Kulyk, M.F., \& Kosenko, M.V. (2001). Mineralne zhyvlennia tvaryn. Kyiv, «Svit» (in Ukrainian).

Kokorev, V., Gur'janov, A., \& Gromova, E. (2005). Optimizacija mineral'nogo pitanija svinej. Svinovodstvo. 1, 11-13 (in Russian).

Lugovoy, S.I., Kramarenko, S.S., \& Lykhach, V.Ya. (2017). Genetic polymorphism of the Landrace pig based on microsatellite markers. Scientific Messenger of Lviv National University of Veterinary Medicine and Biotechnologies. 19(74), 63-66. doi: $10.15421 /$ nvlvet7414

Medvid, S.M., Hunchak, A.V., Gutyj, B.V., \& Ratych, I.B. (2017). Prospects of rational security chicken-broilers with mineral substances. Scientific Messenger of Lviv National University of Veterinary Medicine and Biotechnologies. 19(79),

127-134. doi:10.15421/nvlvet7925

Preedy, V.R., Burrow, G.N., \& Watson, R.R. (2009). Comprehensive Handbook of Jodine: Nutritional, Biochemical, Pathological and Therapeutic Aspects. Acal. Press.

Rud, V.O. (2017). Effects of stress factors on the performance of non-specific resistance and performance of piglets. Scientific Messenger LNUVMBT named after S.Z. Gzhytskyj. 19(74), 114-118. doi:10.15421/nvlvet7425

Suttle, N.F. (2010). Mineral Nutrition of Livestock $4^{\text {th }}$ ed CABI.

Svarchevska, O.Z., Iskra, R.Ia., \& Salyha, N.O. (2014). Hematolohichni pokaznyky krovi porosiat za dii dobavky Tsynku, Khromu, Yodu, Kobaltu i vitaminu S do yikh ratsioniv. Naukovyi visnyk LNUVMBT. 16, 2(59), 295-299.

Vorob'ev, D.V. (2011). Vlijanie preparatov joda i medi na processy metabolizma rastushhih svinej pri gipoelementozah. Agrarnij vestnik Urala. 12, 1(91), 16-19 (in Russian).

Vlizlo, V.V. (2012). Laboratorni metody doslidzhen u biolohiyi, tvarynnytstvi ta veterynarniy medytsyni [Laboratory methods of investigation in biology, stock-breeding and veterinary]. Spolom, Lviv (in Ukrainian).

Zhukova, I.O., Molchanov, A.A., \& Antipin, S.L. (2017). Increase in resistance of pigs to oxidative stress by means of plant origin. Scientific Messenger of Lviv National University of Veterinary Medicine and Biotechnologies. 19(74), 33-37. doi: 10.15421/nvlvet7408 